\title{
ThIRD BiEnNial SCIENTIFIC MEETING OF THE OCEANOGRAPHY SOCIETY: A PERSONAL VIEW
}

\author{
By Melbourne G. Briscoe
}

Hank Stommel once remarked to me that there are four major stages in the life of a meeting-goer:

1. in the early stages of one's career, you try to attend every possible technical session and to listen to every possible paper and discussion because your goal is hitting the subject broadly, not missing anything that might indicate good research directions, and finding out who all those people are whose names you have been reading in journals; you are especially excited by those speakers and posters that show the excitement and enthusiasm of the presenter, for their attitudes are infectious:

2 . in the intensive stage, you tend to limit your attendance to those technical sessions that are specifically on your research area, perhaps attending mainly as a convener or session chairman in order to increase your exposure and to have a bit more influence over the field; you still hit an odd off-research-topic area now and then to add more names and faces to your mental Rolodex; you discover you are intrigued and impressed by those presentations that provide some synthesis and perspective to the field, especially those parts of the field that you increasingly know less and less about as you spend your time learning more and more about some other part of the field;

3 . in the people stage, you get to the technical sessions as possible, but you concentrate on finding people that you want to talk to, either to get specific information from them or to tell them about what you've been working on (to impress them or to solicit feedback); the most valuable parts of the meeting seem to be the coffee breaks, hallways, and

M.G. Briscoe, Secretary, The Oceanography Society. evening dinner sessions; you remark to a colleague that it's a shame the meetings are cluttered with so many technical sessions that get in the way of the really important parts of getting together; and

4 . in the final stage, you go to the meetings and spend your time having people seek you out and ask you questions or tell you about what they've been working on (perhaps trying to impress you or to solicit your opinion and feedback); your best strategy is to find a chair in the middle of the coffee-break area and just wait: it is the Meeting of Dreams: stand there and they will come (Stommel never said it quite this way!).

The first scientific meeting of The Oceanography Society, in Monterey in 1989 , was specifically designed to facilitate Stommel's four stages of meetinggoing. St. Petersburg in 1991 was a tuneup of the style and format, and Seattle in 1993 was a further attempt to provide for the attendees the best possible meeting for all the stages of meeting-going. The morning plenaries particularly address the two early stages of meetinggoing, with an emphasis on a limited number of high-quality presentations that lean toward synthesis and perspective. The afternoon poster sessions and other meeting aspects provide a format that emphasizes person-to-person communication: you can find someone at his or her poster, you can buttonhole them at the continental breakfasts, you can wander around at the big-enough-tohave-them-there but small-enough-tofind-them unhurried receptions, or you can find a good seat and "they will come."

I stood to the side at the Monday evening opening reception and just watched and listened for a while. Walter (and Judy) Munk had placed themselves in a quite convenient location and just stayed there; folks came by to say hello and then passed on to speak with others. The midcareer people were hauling around their students and junior colleagues and introducing them to other mid and senior people. Little groups formed and dissolved. Some intense discussions were taking place, usually involving the meeting organizers, or the Washington (D.C.) program managers and bureaucrats. Jim Baker had a constant stream of mid and senior people coming by to offer their congratulations on his accession to NOAA Administrator; Jim thanked each of them, said a few words, and Emily Baker stood by and smiled (as she undoubtedly tried to memorize names and faces). Monday night was the social hour, the feather preening, the shaking of hands before the main event.

By Tuesday noon, it was clear that it would be a memorable meeting. The first slide from the first speaker was perfect: Margaret Leinen showed a global view of ocean color from the Coastal Zone Color Scanner; this was not going to be a lot of little talks about little ideas or little local regimes, it was going to be substantial presentations that were global, interdisciplinary, and stressed synthesis and "so what?" The first slide from Bill Holland, the modeler, showed Schmitz and McCartney's synthesis of North Atlantic data, suggesting that perhaps modeling was ready to engage in the simulation of the real world rather than the fantasy of toy worlds; progress is being made. Even some of the early one liners were good: Dick Moritz pointing out that, "You can't give a talk, that is too simple."

By Tuesday evening The Oceanography Society's biennial meeting format had been validated: high-quality, plenary, synthesis talks in the mornings 
and high-quality, exciting. informative posters in the afternoons. Jim Swift commented, "Too many posters! There is too much wheat and not enough chaff!" Peter Liss later in the week observed, "The poster sessions are the workhorse of the meeting-they are where the action takes place." And Ned Ostenso summarized, "The mornings are to educate: the afternoons are to inform."

The relaxed feeling that many felt seemed to arise from the chance to listen and absorb and contemplate in the mornings; a chance to have random access at the poster material of choice and collocated exhibits in the afternoons; and plenty of opportunity just to talk with colleagues, program managers, and students.

A remarkable sense of community and continuity grew from the four mornings of plenary sessions and three afternoons of related poster sessions. The speakers later in the week began to refer more and more to ideas or slides of earlier speakers; the speakers referred to the posters, and the groups standing at posters containing details referred to the morning talks that contained synthesis; and little groups of colleagues wandered together from poster to poster, like shipmates cruising through a sea of ideas.

There was a sense of history. Speakers referred back to remarks by Hank Stommel at the first Oceanography Society meeting and quoted The Oceans and Mark Twain. Ken Brink noted that Val Worthington used to kid him about working on the little dirty ring around the bathtub, as Val referred to the coastal zone, and a few talks later Steve Smith concluded that the little dirty ring appeared to be getting dirtier and bigger. Mike McPhaden gave an excellent and heartwarming talk about the Tropical Ocean Global Atmosphere (TOGA) Tropical Atmosphere-Ocean (TAO) array of moorings in the Pacific and how the late Stan Hayes had been the source of the ideas, energy, and enthusiasm to make the project happen; Stan's family was there for the presentation and for Mike's announcement that it had been proposed to name the new NOAA ship being devoted to TOGA-TAO after Stan. I hope it happens.

Some statistics: there were 735 total registrants at the meeting, of which 586 were for the entire meeting and the rest just for the day. Twenty-four percent of the registrants were from the Seattle area, and $29 \%$ were from other than the United States and Canada. For comparison, the two earlier biennial meetings in Monterey (1989) and St. Petersburg (1991) had 537 and 562 total registrants each, respectively. The Oceanography Society has 1,906 members, and most of the registrants were members.

The number of posters at this meeting was 357 , of which 82 were officially by students. The Office of Naval Research and NASA provided some funds to encourage student participation in the meeting: NASA support permitted halfprice student registrations, and the ONR funds made possible five prizes for the best student posters, as selected by a roving panel of 15 very hard-working judges. The winners were D. Byrne, LamontDoherty Earth Observatory-Agulhas Eddies: A Synoptic View; V. Zervakis, Oregon State University - The Near-Inertial Wave Field During Ocean Storms; R. Pawlowicz, Woods Hole Oceanographic Institution-Heat and Salt Budgets in the Central Greenland Sea During 1988-1989 Using Tomographic Measurements; M. Sclafani, McGill University-Condition, Buoyancy, and the Distribution of Larval Fish: Implication for Vertical Migration and Retention; and H. Sosik, Scripps Institution of Oceanography-Photosynthetically Active Absorption and Quantum Yield in the California Current.

Also funded by ONR was the brand new Walter Munk Award for Distinguished Research in Oceanography Related to Sound and the Sea, which was presented-as TOS President Arnold Gordon so correctly pointed out-to probably the only person who fit the criteria exactly, Walter Munk himself. The award consists of a specially designed and cast fine silver medal, a gold tie tack, and a citation. Bob Spindel delivered the citation at the award ceremony, with an inspiring and funny set of remarks, among them his admission that during his student days he read Munk papers that were so famous he was convinced that Munk was dead, since he figured that you had to be dead to be famous. Bob also observed that Walter loves equipment, but "when around it he should be provided with substantial adult supervision." He closed by noting Munk's "unselfish insistence that young people, especially students, be recognized for their contributions." Walter's gracious response to the citation and the award gave honor to the subject of oceanography, his thanks to the Office of Naval Research for their long support of his work and the field, and his high hopes that The Oceanography Society continues to thrive and to foster the growth of a mature, important, professional field of environmental science.

There is a myth about science and scientists that is wrong and misleading. It states that science can only be done well and accurately if the scientist is detached, distant, and unemotional. Hank Stommel knew this was wrong, as the stories about him in the recent issue of Oceanus attest over and over. Cheryl Ann Butman gave a talk Thursday morning in which she commented, "I hope you find this as exciting as I do," and then proceeded relentlessly to make it exciting. The citation by Spindel and the response by Munk, both indicated humanity, humor, and enthusiasm. Arnold Gordon closed the meeting with the story of the Weddell Ice Camp, its excitement and danger, its motivations and adventure, and did it all with humor and clear commitment. This was not dull, detached, unemotional stuff.

The Third Biennial Scientific Meeting, three and a half days in Seattle in 1993, provided its attendees with education, information, strengthened professional unity, a perspective on the past and optimism for the future, and a sure sense of the excitement, humor, and adventure that started the field of oceanography and keeps it alive today. Hank Stommel is gone now, but he would definitely have liked the Seattle meeting. $\square$ 


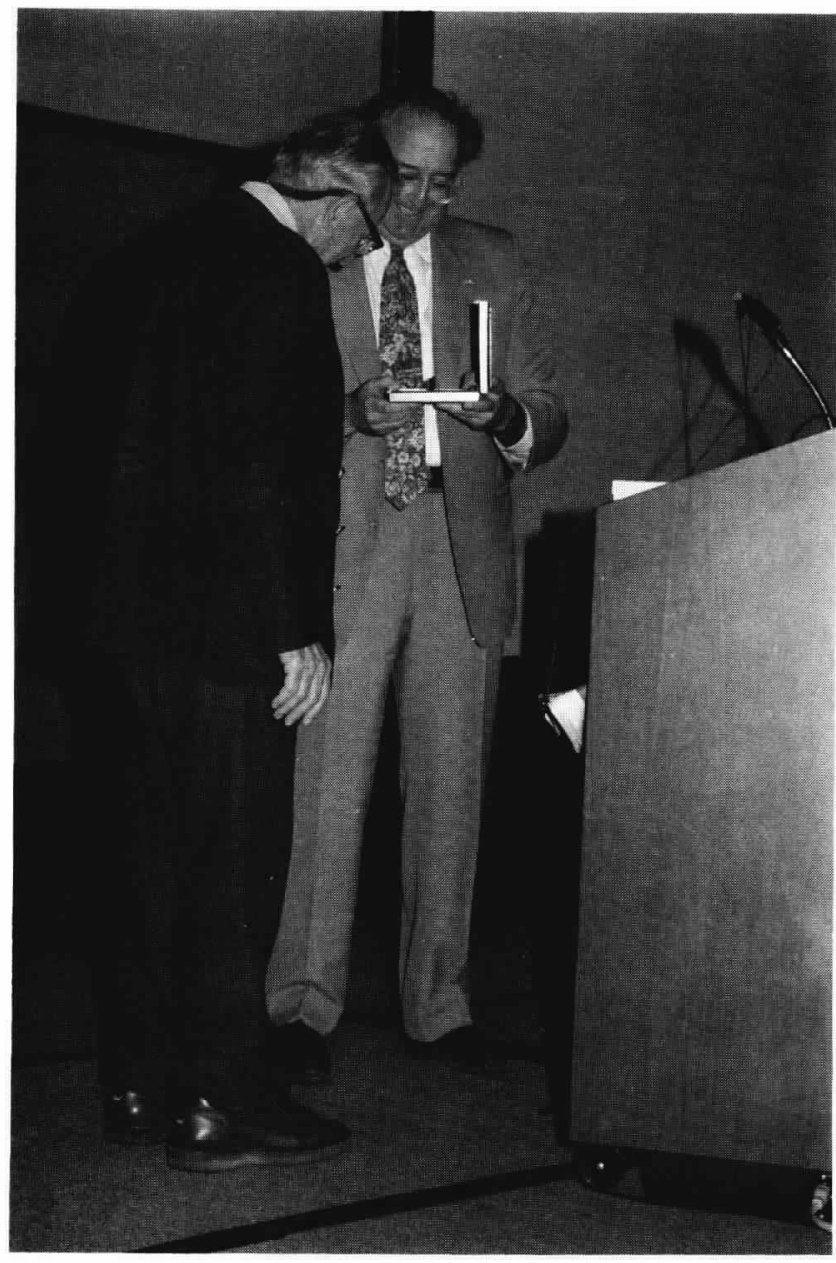

President Arnold Gordon presenting the TOS/ ONR Walter Munk Award for Distinguished Research in Oceanography Related to Sound in the Sea

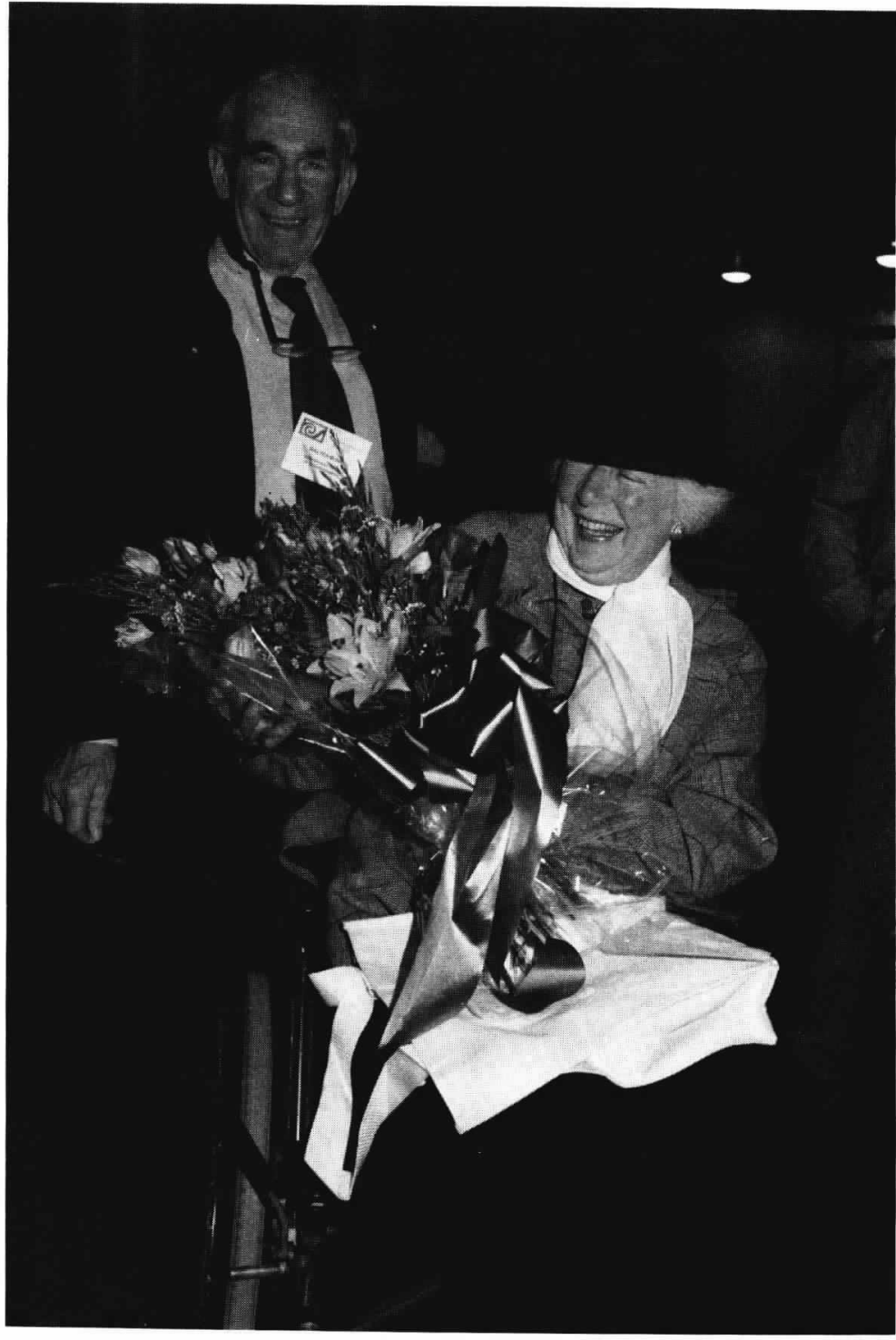

Walter and Judith Munk after presentation of the award
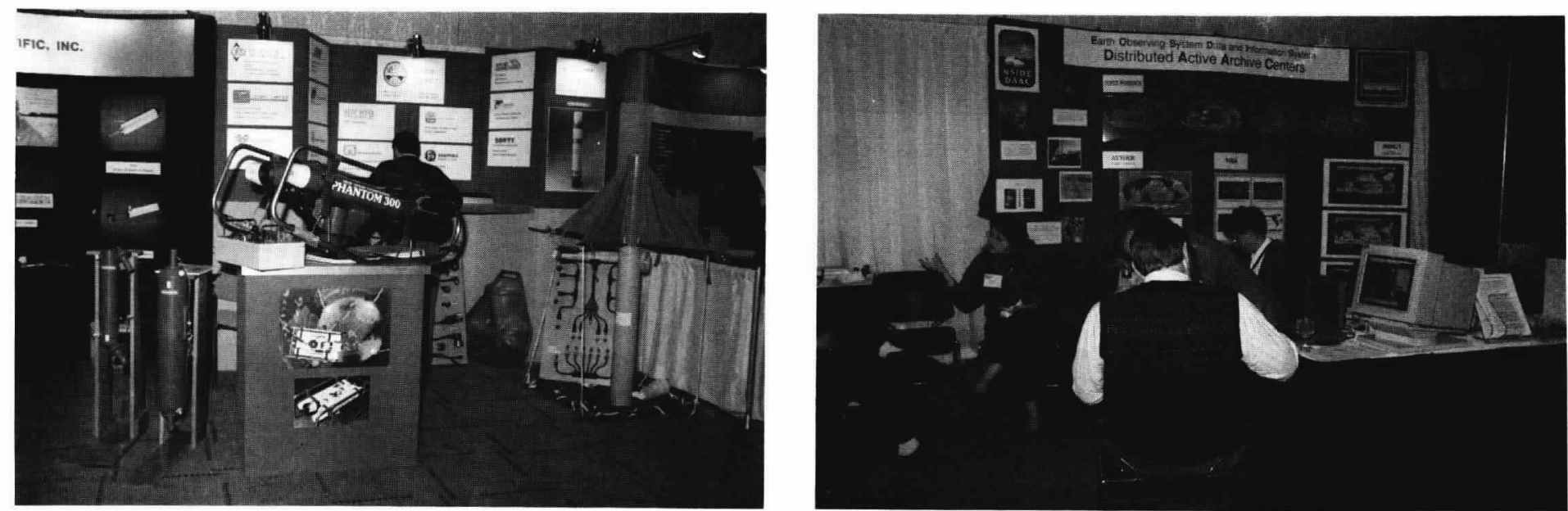